\section{Factors influence banks' advancing approach: Study of emerging economies}

\author{
Damian Honey ${ }^{1}$, Tahseen Mohsan Khan ${ }^{2}$, Malik Umer Ayub ${ }^{3}$
}

The Journal of Educational Paradigms

2019, Vol. 01(02) 64-71

(C) Authors

ISSN (Print): 2709-202X

ISSN (Online): 2709-2038

DOI: $10.47609 / 0102032019$

\begin{abstract}
The study explores the advancing approach of commercial banks of Pakistan and Bahrain influenced by different factors that include loan loss provision, profitability, financial risks, and capital requirement. Hypotheses tested using exploratory analysis and GMM panel regression applied to the data obtained from 26 commercial banks of two countries for the period FY2008 to FY2017. The results reveal a significant connection between advancing approach and loan loss provisions for banks of both countries. Further, the advancing approach establishes a meaningful adverse relationship with profitability and credit risk for banks in Pakistan and with CAR for banks in Bahrain. Overall, the study discovers loan loss provision, profitability, credit risk, and CAR as critical factors having a direct and indirect influence on banks' advancing approaches, which is an addition to the body of knowledge. Interestingly, it observed that the banks are more inclined towards risky assets such as consumer finance must maintain a higher degree of capital adequacy ratio.
\end{abstract}

Keywords: Advancing approach, Loan loss provision, Financial risks, Capital adequacy ratio

The soundness of any country's banking system depends on the efficient development of mechanisms to transfer wealth from surplus to the deficit to derive economic activities within and across countries. The banking system engages its' supportive role towards primary, secondary, and tertiary sectors of the country. The role of banking in any country's economy defined as the circulation of blood within a body. Similarly, the banking system circulates the money within the country to boost the economy. The banking system emergence is not developed overnight. It evolves for centuries through multiple roles that include custodians, facilitators, money lenders, merchants, goldsmiths, etc. Roles cumulatively take care of banking activities according to the need of time. Advancement of trade within and across countries, the banking mechanism also modernizes according to the epoch's need. Banks facilitate different segments of trading activities that include manufacturing, services, and agricultural concerns keeping in view their contributory roles for a country's economic development. One more section that cannot be ignored by any means is individuals having a direct influence on the economy based on variation in their purchasing power. Banks act to meet their needs by providing them consumer loans as a facilitator. The consumer loans categorized into four main categories: the instrument most commonly in use, a credit card, which provides the facility to individuals free from any asset back security. The second category helps to have the possession of a vehicle. The third helps to settle an individual against home appliances or other personal needs and, lastly, the most important one that allows an individual to have shelter. Thus, consumer loans directly linked with the advancing approach of commercial banks. We initiate our study to look at advancing approaches across Pakistan and Bahrain banks influence by loan loss provision (LLP), which are recorded as reserves by the banks on performing part of consumer loans. The comparative trend of gross loans as a proportion of total assets developed that used as a measure for advancing approach to meet study requirements. A decreasing trend is observed in the case of Pakistani banks and an increasing trend in the case of Bahrain banks that can be viewed in figure 1 . The decreasing or increasing trend of gross loan proportion indicates the disintermediation of funds from gross loans to other assets. Our study concludes that banks have been shifting a major part of their portfolios toward risk-free investments to maintain their profitability more efficiently and effectively, like large banks.

Further, we have also developed a comparison of consumer loans as a proportion of both countries' gross loans. It is observed that Bahrain banks are more inclined towards consumer loans with a high degree proportion, which is $50.47 \%$ in 2008 and $69.49 \%$ in 2017. In contrast, Pakistani banks having less reliance on consumer loans with a proportion of $11.08 \%$ in 2008 and $8.03 \%$ in 2017, the difference of degree can be viewed in figure 2. Here we can say Pakistani banks are directly inclined towards economic development by facilitating trading activities compared to Bahrain banks that are indirectly inclined towards economic activities by assisting individuals.

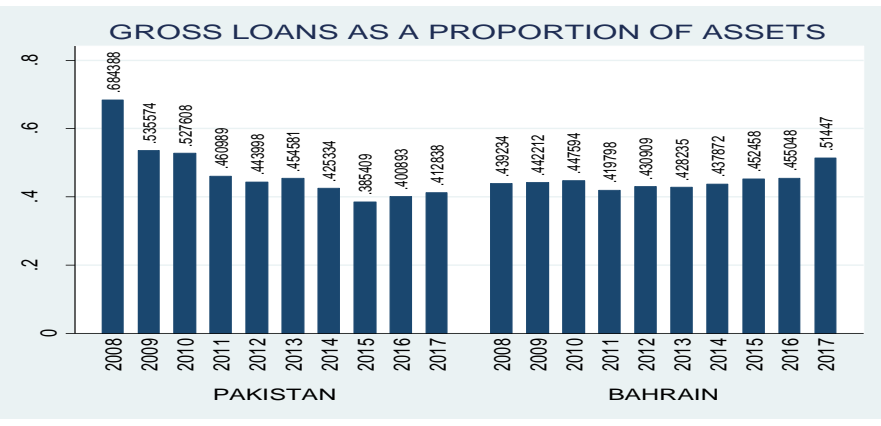

Figure 1: Gross loans Proportion

\footnotetext{
${ }^{1}$ Department of Commerce, Forman Christian College (A Chartered University), Lahore, Pakistan.

${ }^{23}$ School of Business and Economics, University of Management and Technology, Lahore, Pakistan. Email: tahseen.khan@umt.edu.pk.
} 


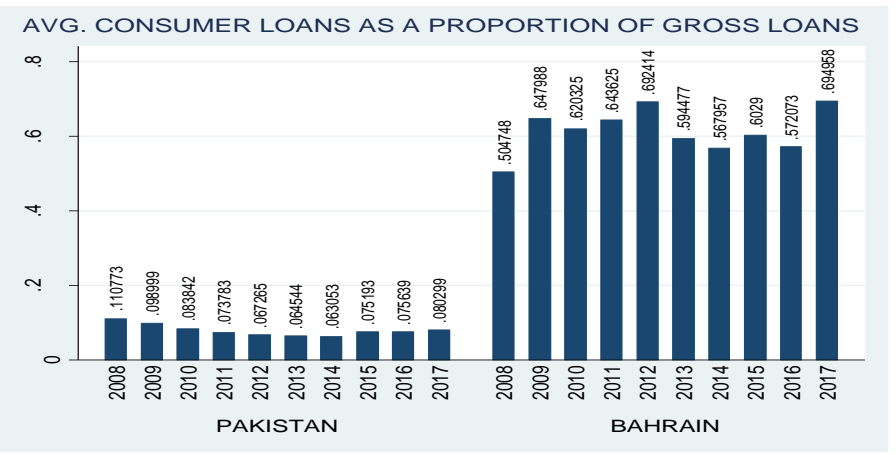

Figure 2: Consumer loans Proportion

Banks do not act as charity institutions, and they perform their functions to take care of their stakeholders' interest that is of wealth maximization and led towards profitability. Banks' critical responsibility is to vigilantly make each loan lending decision by analyzing asset quality and associated risks. Any weak and bad decision by banks may increase the level of non-performing loans, loan loss provision, and write-off portions that may directly influence banks' profitability. According to Basel guidelines, the central banks of each country develop prudential regulations and, if required, may modify by adopting a conservative approach to safeguard the interest of stakeholders. The banks follow central banks'-imposed regulations to record the provisions and associated risks to highlight the banks' actual health to stakeholders. Basel Committee on Bank Supervision (BCBS), from time to time, reviews the global flaw within the banking system and provides recommendations to the central banks for necessary amendments in regulations regarding provisions, associated risks, and others. Basel accord works intending to ensure that financial institutions should maintain enough capital on account to meet obligations and to absorb unexpected losses. As far as BCBS is concerned, it is considered the primary global standard-setter for the prudential regulations of banking systems and provides a forum to address banking supervisory matters. Its' mandate is to strengthen the regulation, supervision, and controls of banks globally to enhance financial stability. Basel, I released in July 1988, the credit risk and minimum capital standard, thereafter further amendments after that market and operational risks. Hence, transformation in banking system initiated in Pakistan since 1990. The results of transformation are observed by HUSAIN (n.d.) and explained as a resultant, sound, and secure banking system, and due to those changes. Several lessons learned from the past suggest that the financial sector functions effectively and efficiently only if the macroeconomic situation is favorable and stable. As a part of Asian financial markets, Pakistan plays a considerable role by providing financial opportunities in different segments of the economy. Bahrain recognizes itself as a leading financial center in the region because of its' contributory role of reinvesting surplus earnings in the oil sector.

The significance of the emergence of Islamic banking cannot be ignored in the case of both emerging economies because of its' rapid growth. Interestingly, both countries operate not only dual banking systems but also their conventional banks operating their Islamic windows. The phenomena of Islamic banking are limited to the extent of the Islamic world. They are also gaining global importance because of its strong fundamentals that consisted of asset-based lending and risk-sharing principles (Islamic Banking Bulletin, 2016). The phenomenon of making money from money by charging interest on interest (Riba) is not only forbidden according to Islamic principles. Still, it is also not accepted in Christianity, Judaism, and Buddhism. The initiative to introduce Islamic Banking in Pakistan launches back in 2001 with state resourcefulness to promote Islamic banking gradually and as a parallel and compatible system aligned with best international practices (Pakistan's Islamic Banking Sector Review, 2007). Islamic banking is followed as a result of the judgment passed by the Shariat appellate bench of the Supreme Court of Pakistan in 1999. The bench consists of Mr. Justice Khalil-ur-Rahman, Mr. Justice Munir A Shaikh, Mr. Justice Wajeehuddin Ahmad, and Maulana Justice Muhammad Taqi Usmani. The court not only take up the matter of interest (equivalent to "riba," thus un-Islamic and illegal) on 23 December 1999 but also upheld the Federal Shariat Court ruling and declaring interest illegal (Dall, 2015).

Bahrain banking system also consists of a dual role like Pakistan that includes both conventional and Islamic banks. The banking sector of Bahrain has also changed since 2008 due to growth throughout 2013 ("Bahrain remains a leading regional center for banking and finance," n.d.). Conventional banks invest their funds in loans to customers and securities. While, the Islamic banks phenomenally act partner through Murabaha, Musharaka, and modaraba, etc. Both banking roles facilitate trading activities and individuals. Weak assets or no securities back individual loans. To take care of stakeholders' interest reserves against performing part of consumer loans are recorded as loan loss provisions. Therefore, loan loss provision is of equal importance for Conventional and Islamic banks (Zoubi \& Al-Khazali, 2007).

The study initiates the comparative analysis by applying exploratory and empirical analysis between Pakistan and Bahrain's banking sectors in terms of measuring loan loss provision, profitability, financial risks, and regulatory capital requirement influenced by the advancing approach. The data is extracted from banks' financial statements over ten years' time horizon (FY 2008 to FY 2017). The rest of the paper is classified into five sections; section two gives data, and methodology follows an overview of both countries' banking regulatory structure. Section three reviews the relevance of existing literature, section four for variables and model specifications, and section five discuss results and conclusions.

\section{Banking regulations in Pakistan and Bahrain Banks Advancing Approach}

The concept of banks advancing approach is explained as a forward-looking approach. Financial stability within the banking sector can only be maintained by evaluating the genuine credit loans need of customers, which is necessary to achieve sustainable economic growth within the country. Another important factor is effective supervision by the regulatory authorities in terms of credit associated risk measures and the possible ways to mitigate it. Regulatory authorities propose financial institutions to create allowance against their risky portfolios and maintain minimum capital based on risk-weighted assets, which banks calculate based 
on their judgment. It also depends on banks' policy to adopt a wise approach to calculating judgmental risk-weighted assets by taking a conservative approach or a flexible approach. The fundamental purpose of creating allowances against risky portfolios and calculating the judgmental risk-weighted assets against credit loans is to meet possible future losses in advance as a forward-looking approach or as an advanced approach. The study uses riskweighted assets as a proportion of gross loans as a measure for advancing approach. Risk-weighted assets influence the advancing approach as a proportion of gross loans shows a decreasing trend but maintains a higher degree compared to Pakistani banks (figure3).

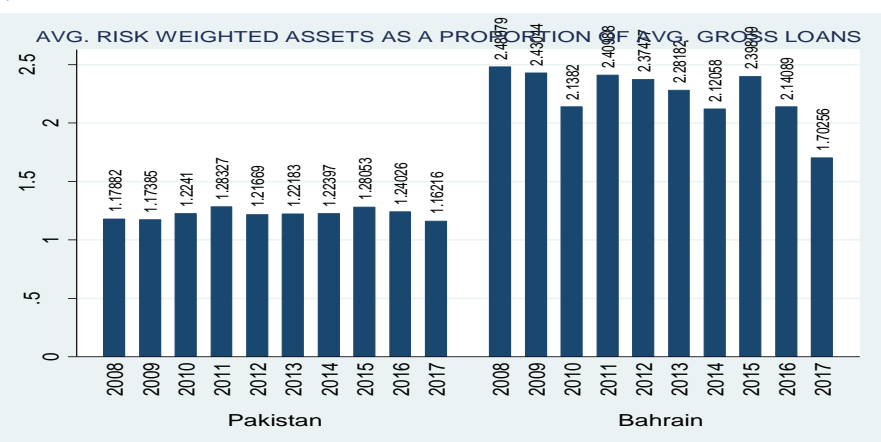

Figure 3: Risk Weighted Assets Proportion

\section{Loan Loss Provision}

Loan loss provisions are reserves recorded against performing part of financial institutions' consumer loans to meet expected losses by the criteria defined by the regulatory authority. In Pakistan, the commercial banks are asked by the regulator to record the general provision ranging from $4-7 \%$ against unsecured consumer loans depending on the non-performing proportion of gross loans. Similarly, it ranges from 1-2.5\% against secured consumer loans. There is also a specific guideline from Central Bank of Bahrain, related to the inclusion of loan loss provisions in tier 2 capital. Such general loan loss provisions eligible for inclusion in tier 2 will be limited to a maximum of 1.25 percentage points of credit riskweighted assets. The study observes the decreasing trend of LLP as a proportion of gross loans in Pakistan and the increasing trend of LLP proportion in the case of Bahrain banks. It also observes the decreasing trend in both banking systems of loan loss provisions as the proportion of consumer loans. The results over the study horizon can be viewed from the undermentioned figure$4 a$ and $4 b$.

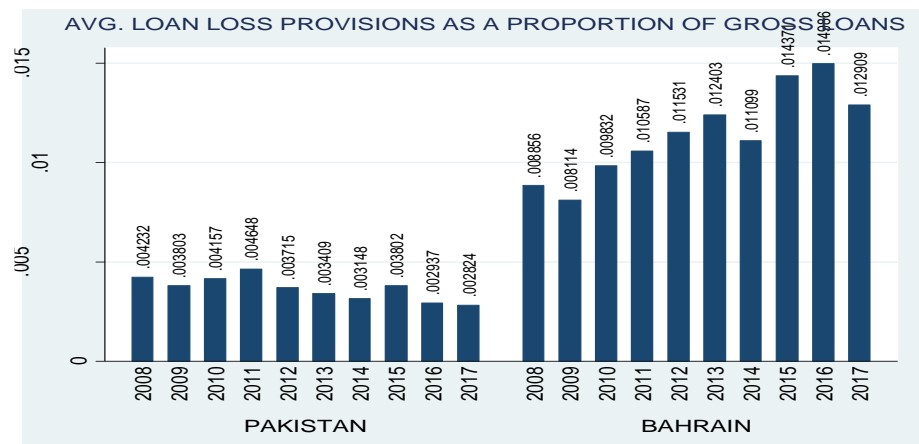

Figure 4a: Loan loss provisions comparison

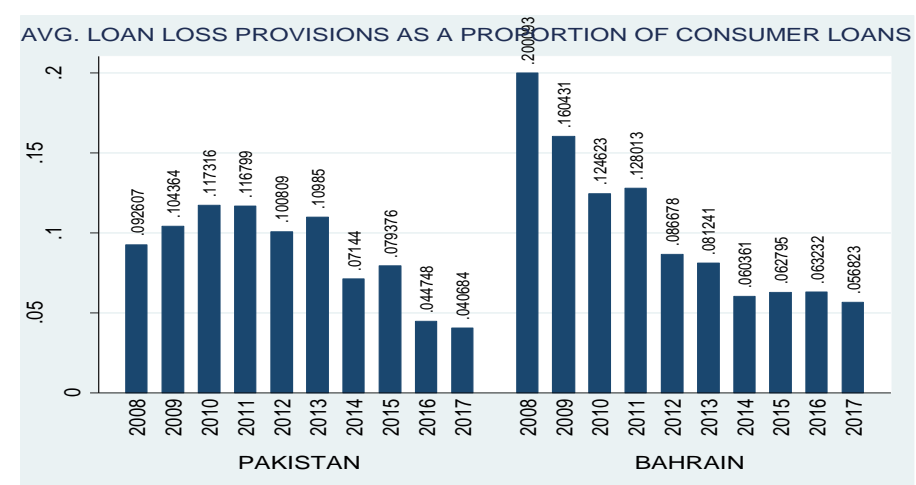

Figure 4b: Loan loss provisions comparison

We further extend our study and observe that the consumer loans of both countries show increasing trends in nominal value over the study horizon. In comparison between the countries, the commercial banks of Pakistan record consumer loans in nominal value equal to $\$ 4083.30$ billion with a loan loss provision of $3.94 \%$ and the commercial banks of Bahrain record consumer loans in a nominal value equal to $\$ 25025.80$ billion with a loan loss provision of $3.85 \%$ for the last year that is 2017 . The results are evident from table 1 and figure 5 .

Table 1: Descriptive statistics for sample banks in nominal values (in \$000)

\begin{tabular}{ccccccc}
\hline Year & \multicolumn{2}{c}{ PAKISTANI BANKS } & \multicolumn{4}{c}{ BAHRAIN BANKS } \\
& CONSUMER & LOAN LOSS & $\%$ & CONSUMER & LOAN LOSS & $\%$ \\
\hline 2017 & LOANS & PROVISIONS & & LOANS & PROVISIONS & \\
2016 & 3263304.82 & 160828.06 & $3.94 \%$ & 25025805.38 & 963397.64 & $3.85 \%$ \\
2015 & 2920248.56 & 142621.13 & $4.36 \%$ & 17354888.10 & 952908.50 & $5.49 \%$ \\
2014 & 2502873.48 & 152518.85 & $5.22 \%$ & 20042732.05 & 887221.58 & $4.43 \%$ \\
2013 & 2266654.03 & 118166.76 & $4.72 \%$ & 18594352.80 & 763649.47 & $4.11 \%$ \\
2012 & 2352505.99 & 99357.84 & $4.59 \%$ & 17575597.37 & 761964.95 & $4.34 \%$ \\
2011 & 2403117.52 & 105453.17 & $4.22 \%$ & 16802789.24 & 720161.06 & $4.29 \%$ \\
2010 & 2882931.66 & 114440.65 & $3.97 \%$ & 15443242.25 & 650621.53 & $4.21 \%$ \\
2009 & 3207586.48 & 92084.09 & $2.87 \%$ & 1580041.81 & 511425.96 & $3.22 \%$ \\
2008 & 3712492.30 & 111290.13 & $3.00 \%$ & 13619920.02 & 439750.38 & $3.08 \%$ \\
\hline
\end{tabular}

Source: Extracted from annual reports of each bank

\section{TOTAL LOAN LOSS PROVISIONS AS A PROPORTION OF TOTAL GROSS LOANS}

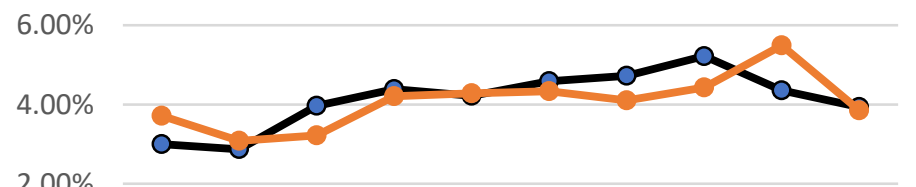

$0.00 \%$

2008200920102011201220132014201520162017

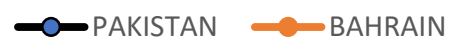

Figure 5: Total Loan loss provisions as a proportion of total gross loans

\section{Financial risks}

The significance of asset quality within the banking sector has a super-priority that causes to associate financial risks, so banks use different tools for financial risk measurement. Banks' provision level can be an important tool to test the excellent health of banks. Provisions are categorized into two categories, one against 
infection within credit portfolios and others are recorded as reserves against performing part of consumer loans. The study clearly shows that banks in Bahrain have a significant reliance on consumer loans, whereas banks in Pakistan on trading loans. Different studies also highlight the significance of banks' associated provisions. A paper describes the importance of provisions as "these provisions for loan losses are of much significance because of involvement of commercial banks in advancing activities to a greater extent as ample room for possible loan default remains" (Ozili \& Outa, 2017). Further, according to Balla, Rose, \& Romero (2012), "Loan loss reserve accounts are an important part of banks' ability to sustain losses." Ahmed, Takeda, \& Thomas (1999) explain that "these provisions may also be used by the stewards of banks to manipulate earnings and capital in some instances."

The financial risks within banks are categorized into three main risks. Firstly, credit risk deals with the default and settlement risk. Secondly, market risk deals with pricing risk due to variation in interest and exchange rate, and finally, operational risk deals with possible failure within the system. The study initiates to assess the potential influence of financial risks on advancing approaches. One of our earlier studies (Khan, Sadiq, \& Mushtaq, 2018) analyzes the relationship between credit risk and bank stability compared between conventional and Islamic banks and between foreign, public, and private banks. And concludes that "Islamic banks are more stable than conventional banks and foreign banks are more stable than public and private banks." This study observes a higher level of credit risk as a proportion of gross loans in Bahrain's case compared to Pakistani banks. It may be because banks in Bahrain were having a higher proportion of consumer loans as part of a portfolio; the results can be observed from figure 6 .

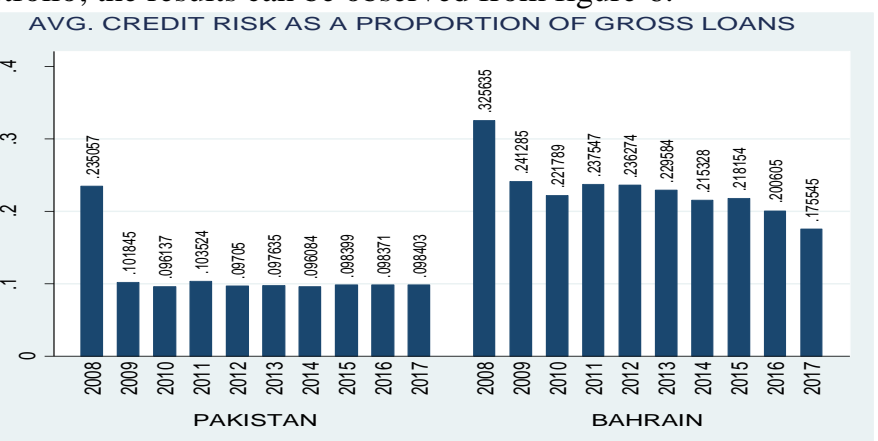

Figure 6: Credit risk proportion comparison

\section{Capital Adequacy Ratio}

The study further initiates to assess the influence of regulatory capital requirements on the advancing approach. Capital requirement explained by Reserve Bank of New Zealand, (2007), "Capital adequacy ratios are a measure of the amount of a bank's capital expressed as a percentage of its risk-weighted credit exposures." State Bank of Pakistan (SBP) is a regulator adopting a conservative approach and asking the banks to maintain regulatory capital for credit, market and operational risks, which should at least be equal to $10 \%$ of total risk-weighted assets compared to Basel II requirement of $8 \%$. Whereas, as per new reforms, the banks are required to meet the capital adequacy ratio equals to $11.275 \%$ by 2017 . As per SBP BPRD (Bank Policy and Regulation department), circular no 06 dated August 15, 2013. wherein SBP has asked banks/DFIs (Development finance institutions) to implement Basel III reforms issued by the Basel Committee on Banking Supervision (BCBS) "to strengthen the capital-related rules further (Arby, 2004). Basel III reforms are in process. The banks must meet a minimum total capital adequacy ratio, including CBB (Central Bank of Bahrain) requirement equal to $12.5 \%$ by 2019 both for Pakistan and Bahrain banks. The study observes that the banks in both countries maintain their capital adequacy ratio above the required criteria. Still, Bahrain banks maintain a higher level of CAR as compared to Pakistan banks. Results can be viewed from figure 7 .

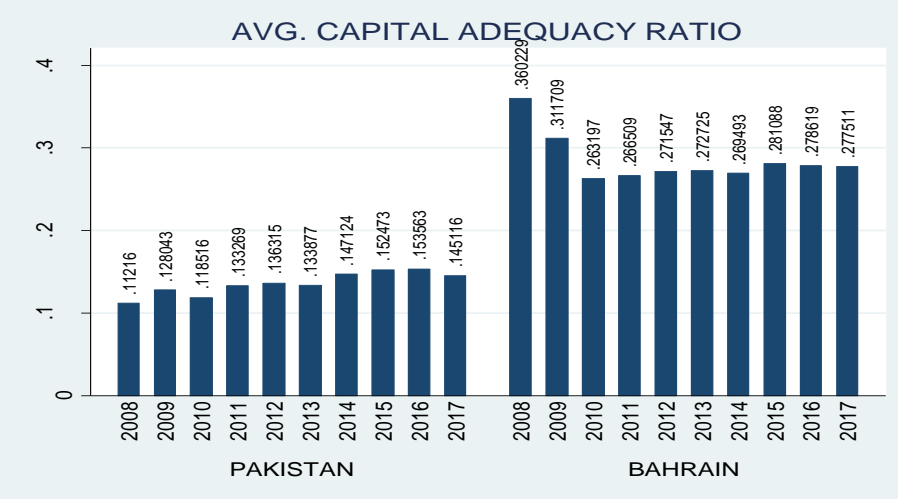

Figure 7: Capital Adequacy Ratio

Literature Review

The study develops a comparative analysis by applying the dataset of commercial banks of Pakistan and Bahrain to analyze the advancing approach influence due to changes in provisions, profitability, financial risks, and regulatory capital requirements. The consequence of our study is to understand how countries take advancing decisions by considering the above-stated determinants. In contrast to previous studies that focus on backward-looking loan loss provisions practices and their impact on lending (Bouvatier \& Lepetit, 2012) and the relationship of loan loss provisions and profitability (Ahmad, Tahir, \& Aziz, 2014). This study focuses on how banks can devise advancing approaches and how various factors influence them.

The study highlights loan loss provision and financial risks as primary factors to influence the advancing approach. According to Angklomkliew, George, and Packer, (2009), loan loss provisions recognized by a backward-looking approach keeping in view the International Accounting Standard (IAS) 39. Which states that loans are said to be impaired when there is objective evidence related to it. To address this shortcoming, the principle of the provision has been modified in the shape of IFRS 9. It is adopted with effect from January 1, 2018, explains it as a forward-looking approach. The adoption of prospective approach provisions is standardized at the time of granting loans by evaluating the probability of expected possible losses. This approach is considered to have fewer deviations compared with the backwardlooking approach.

A study of loan loss provision and profitability in the case of Pakistani banks by Ahmad, Tahir \& Aziz (2014) concludes a negative relationship as they found that less loan loss provisions 
provide more profitability and safety. Similarly, more loan loss provisions give less profitability and instability. We initiate to focus our study by establishing a relation of advancing approach influenced by multiple factors in the banking system of Pakistan and Bahrain as a cushion to existing literature. Consumer loans are considered to be a risky part of banks portfolios because it carries a mix of secured, risky, and unsecured loans. To meet expected losses banks are instructed by regulatory authorities to record Loan Loss provisions as an allowance to manage possible credit risk against consumer loans. Existing literature includes several studies about provisioning. A survey by Cummings and Durrani, (2016) explains that these provisions act as a buffer to preserve a bank's solvency by absorbing existing and estimated future credit losses in the business. These loan loss provisions disclosures follow the conditional conservatism approach that can be beneficial for small banks in terms of reduction in crash risk. Still, the large banks cannot get any benefit from such practice. A study by Andreou, Cooper, Louca, \& Philip, (2017) explains that these provisions act as a buffer to preserve a bank's solvency by absorbing existing and estimated future credit losses in the business for more transparency. Another study by Zoubi \& Al-Khazali (2007) explains that income smoothing, stock pricing, management bonus, signals about future losses and earnings, and compliance with the legal requirement are some objectives that banks usually enjoy with the help of using loan loss provisions. Loan loss provisions may or may not provide any advantage to the banking system, but to meet regulatory impose requirements, banks must record these allowances. A study about the conservative approach as a highlight by Angklomkliew, George \& Packer, (2009) explains that following Asian financial crisis 1997-98 in which severe losses were incurred, most governments in Asia adopted more conservative loan loss provisioning. It is also reported that Central banks and supervisory regulators of Asian countries make their prudential supervision rigorous to ensure that banks have enough reserves and provisions to meet future risks. A study by Najuna \& Ahmad, (2011) addresses the behavior of conventional and Islamic banks in dealing with loan loss provisions and found that both behave differently in terms of capital ratio. Existing research by Liu and Ryan, (1995) makes a linkage between timeliness of loan loss provision to banks' loan portfolio composition and concluded that provisions related to consumer loans are timelier compared to provisions for foreign and commercial loans. Therefore, we have also chosen loan loss provisions to advance approach as one of the factors.

Numbers of literary texts explore the concepts of loan loss provisions due to its importance since the disclosure requirements related to Basel accord. The concept of loan loss provision has been assessed in terms of several areas related to finance and accounting. Research closely related to the current study by Bouvatier \& Lepetit (2012) investigates the backward-looking provision practice and its resultant impact on growth in lending. They further find that LLPs under the backward-looking approach has a significant effect on growth in lending in terms of all countries they consider except for Japan. But our study focuses on how LLPs, profitability, financial risks, and regulatory capital requirements influence the banks in devising their lending approach, by considering this question as to the focal point of our study.

\section{Data and Methodology}

\section{Data Explanation}

The study inducts to have a comparison across countries, and a sample of top 14 Pakistan banks representing 2/3 of Pakistan commercial banks. Assets base and of top 12 Bahrain banks serving $1 / 3$ of Bahrain commercial banks' assets base, 26 in a total of both countries (appendix 1) are used to meet the study requirement. The study is limited to identifying the influence of loan loss provision, profitability, credit risk, market risk, and capital adequacy ratio on advancing approach. The review uses the risk-weighted assets as a proportion of gross loans as a measure for improving approach. The data comprises observations of variables extracted from the commercial banks' annual financial reports of both countries over the time horizon of ten years from FY 2008 to FY 2017. The native currencies are converted to a single currency in US dollars to bring data at par.

\section{Research Objective and Hypothesis development}

Study inducts to analyze the multiple factors that influence banks advancing approach in Pakistan and Bahrain. Based on the study objective and to meet the gap in the existing literature, the undermentioned hypotheses are developed.

Hypothesis 1: Loan loss provisions positively influence the advancing approach of banks.

Hypothesis 2: Profitability of banks positively influence the advancing approach.

Hypothesis 3: Financial risks including credit and market, negatively influence the advancing approach.

Hypothesis 4: Regulatory capital requirement of banks negatively influence the advancing approach.

\section{Methodology}

Strongly balanced panel data of 26 banks operating in Pakistan and Bahrain are used. The study sample covers ten years' time horizon from FY 2008 to FY 2017. The GMM panel regression models are applied separately for each country. In model, we have used the risk-weighted assets as a proportion of gross loans as a measure for advancing approach.

Below is the functional form that we have devised:

\section{Model}

$\mathrm{AA}_{\mathrm{i}, \mathrm{t}}=\alpha_{\mathrm{i}}+\beta_{1} \mathrm{LLP}_{\mathrm{i}, \mathrm{t}} / \mathrm{CL}+\beta_{2} \mathrm{LLP}_{\mathrm{i}, \mathrm{t}} / \mathrm{GL}+\beta_{3} \mathrm{ROA}_{\mathrm{i}, \mathrm{t}}+\beta_{4} \operatorname{lnCR}_{\mathrm{i}, \mathrm{t}}+\beta_{5} \ln \mathrm{MR}_{\mathrm{i}, \mathrm{t}}+\beta_{6} \mathrm{CAR}_{\mathrm{i}, \mathrm{t}}+\varepsilon_{\mathrm{i}, \mathrm{t}}$

Summary of Variables

\section{Dependent Variable}

AA is risk weighted assets as a proportion of gross loans use as measure for advancing approach.

\section{Independent Variables}

- LLP/CL is loan loss provisions as a proportion of consumer loans.

- LLP/GL is loan loss provision as a proportion of gross loans.

- ROA is net income proportion to total assets.

- $\operatorname{lnCR}$ is the natural logarithm of credit risk.

- InMR is the natural logarithm of market risk.

- CAR is total capital as a proportion of total risk weighted assets. 


\section{Results and Discussion Empirical Analysis}

The GMM regression model is run to test the variables. GMM technique is chosen because it can account for inconsistencies and biases in the model due to its dynamic panel estimation approach (Dietrich \& Wanzenried, 2011).

The significant positive relationship between the advancing approach and LLP as a proportion of gross loans for both countries is evident from results. It supports our initial inference for Bahrain banks (table 1). However, the insignificant negative relation between advancing approach and LLP as a proportion of consumer loans is observed for both countries. The significant negative relationship between advancing approach and profitability for Pakistan banks and insignificant positive for Bahrain banks' is observed. The significant negative relation between advancing approach and credit risk for Pakistan banks and insignificant negative for Bahrain banks' is recorded. No association between the advancing approach and market risk is noticed.

Furthermore, the significant negative relation between advancing approach and CAR for Bahrain banks and insignificant positive for Pakistan banks' is observed and contrasts with figure 7. Overall, in the comparison between countries, the model reflects that in terms of Pakistan banks advancing approach has a significant direct relation with LLP as a proportion of gross loans and significant negative association with profitability and credit risk. The advancing approach of banks in Bahrain is significant with LLP's direct influence as a proportion of gross loans and significant indirect impact by CAR. The results can be evident from under mention table 2.

Table 2: Advancing Approach Model-1 (GMM panel regression)

\begin{tabular}{lcccc}
\hline RWA/GL & \multicolumn{2}{c}{ PAKISTAN } & \multicolumn{2}{c}{ BAHRAIN } \\
& Coef. & $\mathbf{P}>\mathbf{z}$ & Coef. & $\mathbf{P}>\mathbf{z}$ \\
\hline LLP_CL & -0.2467 & 0.116 & -0.296 & 0.689 \\
LLP_GL & 16.345 & $\mathbf{0 . 0 2 2}$ & 41.8724 & $\mathbf{0}$ \\
ROA & -3.0096 & $\mathbf{0 . 0 7 3}$ & 3.3321 & 0.656 \\
log_CR & -0.0577 & $\mathbf{0 . 0 8 2}$ & -0.0483 & 0.883 \\
log_MR & 0.0104 & 0.424 & -0.0849 & 0.46 \\
CAR & 0.5415 & 0.371 & -3.2518 & $\mathbf{0 . 0 1 9}$ \\
\hline
\end{tabular}

The study reflects a flash of focus between the emerging economies. It can be viewed that commercial banks in Pakistan are more focused on trade-based concerns, and commercial banks in Bahrain are more focused on consumer concerns in terms of their lending decision making. This decision strategy among both countries can be highlighted from figure- 3 and figure- 6 . The commercial banks in Bahrain have a higher level of risk-weighted assets that leads to maintaining a higher capital adequacy ratio.

It also seems logical that the countries are more inclined towards risky assets like consumer finance must maintain a higher level of capital adequacy ratio. One more factor that is not included in our research is the difference in availability of speedy justice between the countries that matter a lot.

Testing of the Hypotheses

Hypothesis 1: Loan loss provisions positively influence advancing approach of banks.

Loan loss provisions are a crucial element when it comes to the advancing approach of commercial banks, which are regularly involved in accepting deposits and advancing loans to the customers. In our study, we have focused on testing LLPs' influence on advancing approaches. The banks record LLPs as possible future loss reserves against the riskiest advancing by the banks that is consumer loans as per criteria defined by regulatory authorities. As Liu \& Ryan (1995) state, LLPs give a positive indication of the early news of possible loan defaults.

We can observe from the exploratory analysis in figure- 2 that Bahrain banks are ahead of Pakistani banks' in terms of LLPs reserves record as a proportion of gross loans and consumer loans. Further, it can also be observed that the consumer loans of banks in Bahrain are more significant in nominal value (table 1). Though, the result of GMM panel regression establishes a direct relation between advancing approach and LLPs as a proportion of gross loans significant for banks in Pakistan and as well as banks in Bahrain. Thus, our study's findings support H1 is that loan loss provisions positively influence the advancing approach.

Hypothesis 2: Profitability of banks positively influence the advancing approach.

Despite the dependency of the advancing approach of commercial banks on the deposits by the public, there is also a profitability factor contributing to the banks' lending decisions. Perhaps profitability gives the incentive to continue advancing strategy and earn returns in the shape of the spread between the direct and indirect cost of earnings. The result of GMM panel regression establishes an adverse relationship between the advancing approach and profitability of banks in Pakistan and direct relation insignificant for banks in Bahrain. The study's findings do not support $\mathrm{H} 2$ that the profitability of banks positively influences the advancing approach.

Hypothesis 3: Financial risks that include credit and market risks of banks negatively influence the advancing approach.

Financial risk is categorized into three main categories: credit risk, which usually deals with the default and possible delay in settlement. The managers of commercial banks often see credit risk as a factor that directly relates to the advancing approach. It is true; however, it can also be taken as a signal to charge a higher return rate to the borrower as an answer to cover the risk parameters. Hughes \& Moon (2018) find that large banks with assets exceeding $\$ 250$ billion sustain greater inherent credit risk and lower inefficiency in terms of lending. In contrast, small banks face lower credit risk than the large banks but at the stake of highest inefficient lending. Further, during good times, the managers adopt a bit conservative approach that helps them absorb any shock in the future. The result of GMM panel regression establishes an adverse relation between advancing approaches significantly for banks in Pakistan and insignificantly for banks in Bahrain. Hence, results support $\mathrm{H} 3$ that credit risks negatively influence the advancing approach significantly for banks in Pakistan and insignificantly for banks in Bahrain. Further, the results do not establish any significant relation between advancing approach and market risk. Hypothesis 4: Regulatory capital requirement of banks negatively influence the advancing approach.

The risk-weighted assets establish an adverse relationship with the quality of banks' credit portfolio. If fewer would need to be retained as capital, more funds will be available for quality advancement. Brester \& Watts (2018) found that the rise in lending 
leads to a decline in the capital reserve requirement; hence capital reserve requirement is met at the stake of reduced economic activity. This approach supports a risk-averse strategy adopted by the commercial banks of Bahrain.

The result of GMM panel regression establishes a direct insignificant relation between the advancing approach and CAR for banks in Pakistan and adverse significance for banks in Bahrain. Hence, our research findings partially support $\mathrm{H} 4$ that CAR negatively influences the advancing approach for banks in Bahrain.

\section{Conclusion and Recommendation}

The bank's data is collected from the annual reports of 14 commercial banks in Pakistan and 12 commercial banks in Bahrain from FY2008 to FY2017. The study aims to analyze the impact of loan loss provision, profitability, financial risks, and the regulatory capital requirement on advancing approach. Exploratory and empirical analysis through GMM panel regression is applied to compute comparative findings between Pakistan and Bahrain's commercial banks.

Analyzing the advancing approach across the whole study sample it is noticed that commercial banks in both countries follow the advancing approach, but there is a difference of degree. The banks in Bahrain had a higher degree of RWA as a proportion of gross loans compared to banks in Pakistan (figure 3). It may be possible because of a significant part of the portfolio in consumer loans by banks in Bahrain (figure 2) that are considered riskier assets.

The study observes the similarity between countries in terms of the increasing trend of loan loss provisions for banks of both countries (table 1). The empirical analysis depicts a significant direct relation between LLPs as a proportion of gross loans and advancing approaches for both countries. Further, an adverse relationship is noticed between the advancing approach and profitability significant for banks in Pakistan and direct relation insignificant for banks in Bahrain. Credit risk depicts a strong negative association for banks in Pakistan and insignificant for banks in Bahrain. Whereas, no significant association between advancing approach and market risk is recorded. Moreover, a direct insignificant relation between the advancing approach and CAR for banks in Pakistan and indirectly significant for Bahrain banks is recorded.

Overall, the study observes loan loss provision, profitability, credit risk, and CAR as crucial factors having a direct and indirect influence on banks' advancing approaches. Very interestingly, the study also observed that the banks are more inclined towards riskier assets like consumer finance must maintain a higher degree of capital adequacy ratio.

Appendix 1: Sample banks

\begin{tabular}{ll}
\hline Pakistan & Bahrain \\
Bank Names & Bank Names \\
\hline Habib Bank Limited & Kuwait Finance House \\
Muslim Commercial Bank & Khaleeji Commercial Bank \\
United Bank Limited & Al Salam Bank \\
Standard Chartered Bank & Bahrain Islamic Bank \\
Askari Bank Limited & Bank of Bahrain and Kuwait \\
Bank Alfalah Limited & National Bank of Bahrain \\
Bank of Punjab & Eskan Bank of Bahrain \\
Faysal Bank Limited & Arab Banking Corporation \\
Habib Metropolitan Bank & Al Baraka Banking Group \\
Meezan Bank & Ithmaar Bank
\end{tabular}

Soneri Bank Limited

Summit Bank

Ahli United Bank

Gulf International Bank

\section{References}

Ahmad, F., Tahir, S. H., \& Aziz, B. (2014). Impact of loan loss provision on bank profitability in Pakistan. Research Journal of Social Sciences \& Management, 3(April 2014).

Ahmed, A. S., Takeda, C., \& Thomas, S. (1999). Bank loan loss provisions: A reexamination of capital management, earnings management and signaling effects. Journal of Accounting and Economics, 28(1), 1-25. https://doi.org/10.1016/S01654101(99)00017-8

Andreou, P. C., Cooper, I., Louca, C., \& Philip, D. (2017). Bank loan loss accounting treatments, credit cycles and crash. The British Accounting Review, 1-19. https://doi.org/10.1016/j.bar.2017.03.002

Angklomkliew, S., George, J., \& Packer, F. (2009). Issues and developments in loan loss provisioning: the case of Asia. BIS Quarterly Review, (2009), 69-83.

Arby, M. F. (2004). The State Bank of Pakistan: Evolution, Functions, \& Organization. Retrieved May 2, 2017, from http://www.sbp.org.pk/about/banks_nbfis/capitalbanks/creq1.ht $\mathrm{m}$

Bahrain remains a leading regional centre for banking and finance. (n.d.). Retrieved from https://www.oxfordbusinessgroup.com/overview/bahrainremains-leading-regional-centre-banking-and-finance

Balla, B. E., Rose, M. J., \& Romero, J. (2012). Loan Loss Reserve Accounting and Bank Behavior. The Federal Reserve Bank of Richmond Publications, (March), 1-4.

Banking. (n.d.). Retrieved September 4, 2017, from http://www.cbb.gov.bh/page-p-banking.htm

Bouvatier, V., \& Lepetit, L. (2012). Effects of loan loss provisions on growth in bank lending: some international comparisons. International Economics, 132, 91-116.

Brester, G. W., \& Watts, M. J. (2018). The Basel accords, capital reserves, and agricultural lending. Agricultural Finance Review, AFR-04-2017-0025. https://doi.org/10.1108/AFR-04-20170025 CBB Volume 1: Contents. (n.d.). Retrieved September 5, 2017 , from http://cbb.complinet.com/cbb/display/display.html?rbid=1820\& element_id=11629

Cummings, J. R., \& Durrani, K. J. (2016). Effect of the basel accord capital requirements on the loan-loss provisioning practices of Australian banks. Journal of Banking \& Finance, 67(December 2003),

23-36. https://doi.org/10.1016/j.jbankfin.2016.02.009

Dall, F. (2015). The Riba Case And The Interest Based Financial System Of Pakistan. Retrieved from http://courtingthelaw.com/2015/09/21/commentary/the-ribacase-and-the-interest-based-financial-system-of-pakistan/

Dietrich, A., \& Wanzenried, G. (2011). Determinants of bank profitability before and during the crisis: Evidence from Switzerland. Journal of International Financial Markets, Institutions and Money, 21(3), 307-327. https://doi.org/10.1016/j.intfin.2010.11.002

Hughes, J. P., \& Moon, C.-G. (2018). How Bad Is a Bad Loan? 
Distinguishing Inherent Credit Risk from Inefficient Lending ( Does the Capital Market Price This Difference?). Working Paper, No. 2018-02

HUSAIN, I. (n.d.). Pakistan Banking Sector. Retrieved from https://ishrathusain.iba.edu.pk/speeches/WordDocs/Pakistan_B anking_Sector.doc\%0A

Islamic Banking Bulletin. (2016). Islamic Banking Department State Bank of Pakistan. Retrieved from www.sbp.org.pk/ibd/bulletin/2016/Jun.pdf

Liu, C. C., \& Ryan, S. G. (1995). The effect of bank loan portfolio composition on the market reaction to and anticipation of loan loss provisions. Journal of Accounting Research, 33(1), 77-94.

Misman, F. N., \& Ahmad, W. (2011). Loan loss provisions: Evidence from Malaysian Islamic and conventional banks. International Review of Business Research Papers, 7(4), 94-103.

Ozili, P. K., \& Outa, E. (2017). Bank loan loss provisions research: A review. Borsa Istanbul Review, 17(3), 144-163. https://doi.org/10.1016/j.bir.2017.05.001

Pakistan's Islamic Banking Sector Review. (2007). Islamic banking department state bank of pakistan. Retrieved from www.sbp.org.pk/ibd/Islamic-Bkg-Review-03-07.pdf

Reserve Bank of New Zealand. (2007). Capital adequacy ratios for banks - simplified explanation and example of calculation, 1-9. Retrieved from http://www.rbnz.govt.nz/finstab/banking/regulation/0091769.ht $\mathrm{ml}$

Zoubi, T. A., \& Al-Khazali, O. (2007). Empirical testing of the loss provisions of banks in the GCC region. Managerial Finance, 33(7), 500-511. https://doi.org/10.1108/03074350710753771 